\title{
Seed sows further doubts on cloning
}

\section{Meredith Wadman}

\section{Plans by a Chicago embryologist to clone a human being have renewed pressure for swift action to ban the practice in the United States. But scientists warn that an ill-drafted law could stifle genuine research.}

[WASHINGTON] The provocative pronunciations of Richard Seed of Chicago, a Harvardtrained physicist who last week announced plans to clone a human being, appear to bear little relationship to reality. Seed has little money, few if any fertility physicians willing to help him, and no laboratory.

Furthermore, prohibitive scientific obstacles remain to such a feat. It took the Scottish scientist Ian Wilmut and his team 277 attempts to produce Dolly, the clone of an adult ewe (see Nature 385, 810; 1997), and nothing suggests that the effort in humans is going to prove any easier.

"This has been played on front pages as though there's something to announce," says Alexander Morgan Capron, a professor of law and medicine at the University of Southern California who is a member of the National Bioethics Advisory Commission (NBAC). "My own sense is that it belongs in the entertainment section."

But, however dubious its origins, the tempest set off by Seed's announcement points to the fact that, at least in the United States, cloning a human being using private funds would break no law.

That could soon change. Seed "will not

do human cloning in this country," declared Donna Shalala, Secretary of Health and Human Services, on CBS television last Sunday (11 January). And President Bill Clinton, in his weekly radio address last Saturday, called Seed's announcement "profoundly troubling" and urged Congress to enact legislation when it reconvenes this month. "There is virtually unanimous consensus in the scientific and medical communities that attempting to use these cloning techniques to clone a human is untested and unsafe and morally unacceptable," Clinton said.

He added that Seed's plans make it "clearer than ever" that cloning legislation he sent to the Congress last June is "exactly what is needed” (see Nature 387, 644; 1997). Clinton's Cloning Prohibition Act would ban for at least five years the cloning of human beings in the public and private sectors.

So far Congress has not acted on it. But the mood of legislators appears to be rapidly changing. Speaking on US television last Sunday, the House of Representatives majority leader, Richard Armey, declared Seed's project a "nasty business". Referring to a House bill already introduced by congressman Vern Ehlers (Republican, Michigan),

\section{US ban 'would resist challenges in court'}

[WASHINGTON] The increasing

likelihood that the US

Congress will pass legislation

outlawing human cloning

immediately raises

constitutional questions.

Would such a ban withstand

court challenges that it

breaches the freedom of

scientific enquiry, for

example? And would it

violate a right to reproductive freedom?

Constitutional scholars

interviewed last week

suggest that, if a cloning law were challenged and the

case reached the US

Supreme Court, arguments for neither procreative nor scientific liberty would hold sway.
According to Richard

Fallon, a professor of

constitutional law at the Harvard Law School, with human health so evidently at risk, the right to freedom of scientific enquiry, which has some basis in lower court decisions, would appear "frivolous".

Neither would the more powerful argument ultimately triumph that couples should have a right to reproduce without government interference, say legal scholars.

"What the court would be likely to say is that there's a difference between reproduction and replication," says Cass Sunstein, a professor of law at the University of Chicago.

Sunstein suggests that the court would probably rule that earlier decisions establishing some rights of reproductive freedom do "not extend to an unfettered right to reproduce by whatever technology science comes up with".

Even if such a right were to be acknowledged, he and others suggest that the state would have sufficient ammunition to argue convincingly that that right should be outweighed by the need to protect developing fetuses and resulting babies from any undue physical harm. M.W.

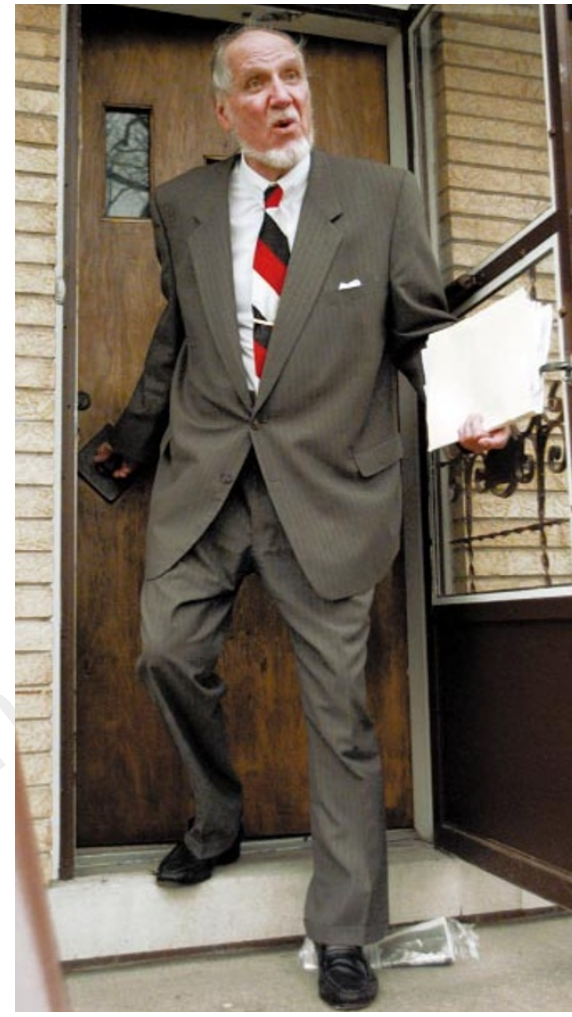

Out of step: Seed faces opprobrium from the scientific community as well as legal hurdles.

Armey said: "We are going to move that ban." And Senator Bill Frist (Republican, Tennessee), the cardiac surgeon who chairs the Senate subcommittee that has jurisdiction on the issue, told Nature through a spokeswoman that he is considering introducing legislation to this end. "If Richard Seed gets credit for anything, it's for putting this issue back before Congress," says Capron.

The lack of action in Congress has occurred despite a flurry of hearings that followed the announcement last February of Dolly's birth, the recommendation last June by NBAC that Congress should outlaw human cloning for a period (see Nature 387, 217; 1997), and the submission to Congress of Clinton's bill, which in essence codifies the commission's recommendation.

Three bills authored by congressmen have also languished - two of them would bar federal funding for research on cloning humans and one would impose civil fines on anyone who produces a human clone (see Nature 386, 97; 1997).

Before Seed's announcement, Frist had been reluctant to legislate. The chairman of the public health subcommittee of the Senate Labor and Human Resources Committee said in October that "there is no reason for Congress to legislate" and that the issue ought instead to be debated in a "national dialogue".

According to Margaret Camp, a spokeswoman for Frist, the senator thought until last week that a voluntary private sector moratorium on cloning called for by Clinton in March was being followed. That, com- 
bined with a ban on federal funding for human cloning imposed by Clinton at the same time, was considered by the senator to be sufficient. But, says Camp, Frist is now reconsidering his position in the light of Seed's announcement. "He is looking at legislation now. But it's with human cloning [for reproductive purposes]. He feels strongly about protecting research."

Behind the congressional inaction on cloning over the last ten months has been not only a busy schedule in which the issue got pushed aside, but also abortion politics, as exemplified in the fate of the Clinton bill (see Nature 387, 748; 1997).

Despite courting Republicans and Democrats in the House and Senate, and support for the bill's approach from groups such as the Biotechnology Industry Organization, the White House has been unable to find a sponsor for the bill. This is partly because the bill - like the recommendations of the NBAC - does not prohibit use of cloning techniques in human embryo research.

Even Connie Morella, the liberal Republican congresswoman who represents the Maryland constituency that includes the National Institutes of Health, has not stepped forward to sponsor the legislationalthough the White House courted her. Morella called last week for a bill to ban human cloning.

"Nobody in Congress wanted to touch [the Clinton bill] with a ten-foot pole," says Roger Pedersen, a mammalian embryologist at the University of California, San Francisco, who speaks for the Federation of American Societies for Experimental Biology (FASEB). The federation, which represents 52,000 sci-

\section{Europe brings in first international ban}

[PARIS] At a ceremony in Paris on Monday (12 January), 17

European countries signed a protocol added to the European Convention on Human Rights and Biomedicine that bans the use of human cloning for reproductive purposes - the first legally binding international agreement to do so.

Two countries were conspicuous by their absence among the signatories: the United
Kingdom and Germany. Neither can sign the protocol because they have not signed the convention itself, the United Kingdom because of delays caused by the change in government, and Germany because it feels the provisions in the convention concerning human embryo research and consent by incapacitated individuals are not strict enough.

ButBritish legislation setting up the Human Fertilization and Embryo
Authority already forbids the use of human cloning, and human cloning for reproductive purposes is banned by law in Germany.

The signing of the agreement was welcomed by Jacques Chirac, the French president. Speaking at a meeting of Europe's ethics committees in Paris, Chirac said that an international ban was essential as otherwise the technology would migrate to countries where regulation was less strict. Declan Butler

entists, is pushing a different approach. In September, following the lead of the Society for Developmental Biology, it adopted a voluntary moratorium on cloning.

Since then, the American Society for Reproductive Medicine, representing 9,000 fertility physicians, and the Society for the Study of Reproduction, with 2,400 members, have adopted the same moratorium. Pedersen says the opprobrium heaped on Seed by fellow scientists last week is evidence of the power of peer pressure in the face of aberrant behaviour. "There's a circling of the wagons, with him outside," he says.

Although FASEB does not condone human cloning at this stage, he adds, "Congress has been acting responsibly by not rushing legislation. Hastily written law can do more harm than good by deterring poten-

\section{Unesco declaration lacks legal teeth}

[PARIS] Richard Seed's declared intention to set up a cloning laboratory in Tijuana, Mexico, if the US Congress bans human cloning was quickly rebutted by the Mexican government, which lastFriday expressed its "broadest repudiation" of Seed's proposal.

But, like Seed's challenge to the US Congress, his offshore plans point out another reality: the international community has no solid legal front to present against the planned work of Seed or those who may follow him. Not only could Seed now proceed in Mexico - where the president of the national bioethics commission last week could only implore the Mexican
Congress to legislate on the matter - but no binding international ban on cloning is now in place.

The 186 member states of the United Nations Educational, Scientific and Cultural Organization unanimously passed a declaration in November calling for a cloning ban (see Nature 390, 110 \& 388, 508; 1997). But that declaration is not legally binding.

Noëlle Lenoir, the chairwoman of Unesco's International Bioethics Committee, says the committee cannot take a position on the need for a legally-binding international agreement, as it has frozen its activities pending a review of its functions to fulfil the new mandate given to it by Unesco of following up the implementation of the provisions of the declaration. The new committee, which should be in place next month, will probably consider whether a legal instrument is desirable.

Turning the call for a ban on cloning for reproductive purposes contained in the declaration into a legallybinding agreement may in practice change little, argues Lenoir. What is important is that countries translate international agreements into their national laws and enforce them. "Pressure for international agreements counts for little unless there is national government will to implement them." M.w.\&.D.B. tially beneficial research. That's why I think a voluntary moratorium is more effective."

But Capron of the NBAC says that congressional inaction has resulted in domestic and international US failures. Domestically, he says, it has allowed a "cowboy" like Seed to pursue his ends unchallenged. And internationally, the fact that the United States has not condemned human cloning officially by passing the Clinton legislation "means that we're not in a leadership position".

The Clinton legislation would ban the use of cloning to create children by anyone in the private or public sector. It would expire after five years, before which time the NBAC would be required to review developments and recommend whether the law should be extended. It includes explicit protections for cloning's research applications in DNA, cells, tissues and animals, but does not mention human embryo research. Embryo research - whether or not using cloning technology - is at present legal if financed privately, but barred from federal funding.

Scientific groups have said that they fear that, unlike the Clinton bill, those introduced by congressmen are so broadly worded and imprecise that they threaten research. A Senate bill introduced last February by Christopher Bond (Republican, Missouri) would bar the use of federal funds for "research with respect to the cloning of a human individual". Bond said last week that he would push for a broader "emergency ban" to encompass the private sector.

Two House bills were introduced last winter by Vern Ehlers. One banned federal funding for "research that involves the use of a human somatic cell for the process of producing a human clone". The other imposed a penalty of up to $\$ 5,000$ on anyone "producing a human clone". Ehlers later expanded the first bill to include a ban on use of cloning in human embryo research. The House Science Committee approved it last July; it had to be rewritten to win enough votes to be passed by the committee. 